\title{
The Scope of Stem Cells in Periodontal Regeneration
}

\author{
Thomas George V*, Nebu George Thomas, Saumya John and Prameetha George Ittycheria \\ Department Of Periodontics, Pushpagiri College of Dental Sciences, Kerala, India
}

Received: February 18, 2015; Accepted: May 20, 2015; Published: June 05, 2015

*Corresponding author: Dr. Thomas George V, Department Of Periodontics, Pushpagiri College of Dental Sciences, Kerala, India, Tel: +919447429281; E-mail: thomasgeorge@rediffmail.com

\begin{abstract}
Chronic periodontitis is an inflammatory disease, resulting in destruction of the supporting structures of teeth. The ultimate goal of periodontal therapy is the regeneration of these lost structures. Stem cells are the latest entrant in periodontal regeneration. Amongst which, Dental Mesenchymal Stem Cells (DMSC) are currently the focus of research as these cells can be harvested with considerable ease and are associated with minimal donor morbidity. Hence this review has dealt in detail with all the different DMSC available, the various characteristics which support their capability to differentiate into periodontal cells, and the extent to which they have been utilized in periodontal regeneration. Also, we have drawn attention to cell sheet engineering, which is presumed to be the next level of tissue engineering and has shown promising results in periodontal regeneration.
\end{abstract}

Keywords: Mesenchymal stem cells; Dental mesenchymal stem cells; Periodontal ligament stem cells; Cell sheet engineering

\section{Introduction}

Chronic periodontitis is a disease of the periodontium characterized by irreversible damage in connective tissue attachment and supporting alveolar bone [1]. This destruction will lead to a functionally and esthetically questionable dentition. National surveys have shown that around 35\% of adults suffer from moderate periodontitis, while $15 \%$ are affected by severe generalized periodontitis at some point [2]. These statistical results show the severity of periodontal disease and its impact on general health of the world population. Hence there has been an increased interest in the management of periodontal disease and as a result, improve the patient's quality of life [3]. However, conventional treatment modalities like scaling, curettage and open flap debridement result in control of inflammation and formation of a long junctional epithelium and hence only periodontal repair and no regeneration [4].

Several procedures have been attempted to achieve periodontal regeneration, which include root surface conditioning agents, bone grafts, guided tissue regeneration and growth factor application [5-11]. Ramsier, et al. [12] suggested that surgical regenerative therapy is best suited for deep infrabony defects.
There are several drawbacks associated with conventional regenerative techniques which have been described in the Table 1 [13-21].

Tissue engineering as proposed by Langer, et al. [22] comprises of multiple progenitor cells, signaling molecules and conductive extracellular matrix scaffold, along with an adequate blood supply [22-25]. Scaffolds act as the extracellular matrix creating an environment suitable for cell proliferation and differentiation for a limited period of time [26]. Hence scaffolds should fulfill certain requirements such as shape, pore size, rate of porosity to provide a viable extracellular matrix to the cells [27]. Signaling molecules also referred to as immunomodulatory polypeptides are essential to enhance cellular activities such as cell proliferation, differentiation, migration and apoptosis $[28,29]$. Finally progenitor cells or stem cells thriving within the scaffolds process the signals and carry out tissue regeneration. According to Hynes, et al. [30] the most critical component of tissue engineering is the choice of stem cell population [30]. Currently studies on stem cells have made an achievable progress as a potential application in regenerative periodontal therapy

Table 1: Limitations of conventional regenerative techniques.

\begin{tabular}{|c|c|}
\hline \multirow[b]{2}{*}{ Bone Grafts } & $\begin{array}{l}\text { autogenous bone grafts-donor site morbidity and } \\
\text { complications; limited graft availability [13-15] }\end{array}$ \\
\hline & $\begin{array}{l}\text { xenografts and alloplasts associated with only } \\
\text { osteoconductive property and prone to fibrous } \\
\text { encapsulation [16] }\end{array}$ \\
\hline EMD & $\begin{array}{c}\text { limited predictability and high degree of variability } \\
\text { in results }[17,18]\end{array}$ \\
\hline PRP & $\begin{array}{l}\text { limited predictability and high degree of variability } \\
\text { in results }[17,18]\end{array}$ \\
\hline \multirow{4}{*}{ GTR } & $\begin{array}{c}\text { resorbable membrane are collapsible hence placed } \\
\text { along with bone grafts [19] }\end{array}$ \\
\hline & $\begin{array}{l}\text { non-resorbable membrane prone to infection and } \\
\text { and require surgical re-entry procedure [19] }\end{array}$ \\
\hline & $\begin{array}{c}\text { significant results in case of narrow } 2 / 3 \text { walled } \\
\text { defects, circumferential defects, class } 2 \text { molar } \\
\text { furcations [20] }\end{array}$ \\
\hline & no effect in class 3 molar furcations [21] \\
\hline
\end{tabular}


amongst which mesenchymal stem cells are gaining considerable interest due to their unique properties [31-34]. Hence we have focused on the scope of stem cells in periodontal regeneration. Stem cells used so far in periodontal regeneration have been identified, and their characteristics that aid in periodontal regeneration, and various methods used to incorporate them examined in detail.

\section{Stem Cells}

They are defined as clonogenic cells, which are capable of both self-renewal and multi-lineage differentiation [35]. According to their origin and differentiation potential, stem cells are classified as:

- Embryonic stem cells

- $\quad$ Adult stem cells

- Induced pluripotent stem cells

\section{Embryonic stem cells}

They are derived from the inner cell mass of blastocyst stage of embryonic developments, prior to implantation in the uterine wall. They are pluripotent stem cells, which imply that they are capable of giving rise to cells of all three germ layers [36]. They are responsible for the formation of an individual from an embryo, and they disappear by the time adulthood is attained. Hence embryonic stem cells are the best source of cells for periodontal regeneration due to their high pluripotency.

A bioengineered tooth was developed by Nakao, et al. [37] using murine embryonic stem cells derived from epithelium and mesenchyme, which was able to erupt from the oral cavity of the mouse and develop into a fully functional tooth.

Embryonic stem cells are ideal for periodontal regeneration. However, their use in clinical therapy has been hampered by ethical concerns [38]. Another important disadvantage is that, their implantation in the human body has been associated with the occurrence of rare cancers [36].

\section{Adult stem cells}

The adult stem cells are basically undifferentiated cells found among differentiated cells in a tissue organ. They are also referred to as Mesenchymal Stem Cells (MSC). They have a characteristic feature of being able to proliferate and differentiate to yield the major specialized cell types of the tissue or organ. Also, they adhere to plastic and have specific surface antigens (CD105, CD73, and CD90). Adult stem cells are found in the majority of fetal and adult tissue example: peripheral blood, dermis, gastrointestinal epithelium and brain [39-41].

Bone Marrow derived Mesenchymal Stem Cells (BMMSC): The main source of adult stem cells is the bone marrow in proportion of 1 in 34,000 of nucleated cells. MSCs derived from the bone marrow are referred to as bone marrow derived mesenchymal stem cell (BMMSC) and have been the most studied amongst mesenchymal stem cells [42-44].

They are characterized by embryonic stem cell markers Oct-4 and Nanog, and also express MSC markers CD73, CD90, CD105, CD106 and CD166 [45]. BMMSCs have been found to be capable of differentiating into various cell lineages like osteoblasts, chrondocytes and adipocytes [36,44,46]. BMSSCs have been shown to form cementum, periodontal ligament and alveolar bone, suggesting that bone marrow may be a useful source for periodontal regeneration [46].

They have been incorporated in class III furcation defects in canine models resulting in successful results [47]. BMMSCs were present in the defect even after 1 month, suggesting that they ultimately form various periodontal cells needed for regeneration [47]. Also, Yamada, et al. [48] managed to successfully carry out periodontal regeneration using autologous BMMSCs and plateletrich plasma.

Since harvesting BMMSCs is associated with certain limitations such as pain, morbidity and decreased number of cells obtained, therefore alternate sources for obtaining MSCs to carry out periodontal regeneration have been sought.

Dental MSCs: MSCs has been found in various dental tissues. These are easier to harvest and associated with lesser patient related complications. The various dental MSCs that has been found till date to be useful in periodontal regeneration as illustrated in Table 2 and Figure 1 include:

Dental pulp stem cells (DPSCs): In an investigation, Gronthos, et al. [49] isolated from adult human dental pulp a clonogenic, rapidly proliferative population of cells which were found to be similar to BMSCs. In vitro characterization reveals mesenchymal stem cell markers such as STRO-1, CD31 and CD146 and also embryonic stem cell markers Oct-4 and Nanog [41]. They also express a mesenchymal marker vimentin [50,51].

Human derived DPSCs along with hydroxyapatite or beta tricalcium phosphate have been reported to be capable of forming bone and cementum $[49,50,52]$. However, some authors are skeptical about the role of these cells in periodontal regeneration. Carinci and coworkers isolated a subpopulation within the

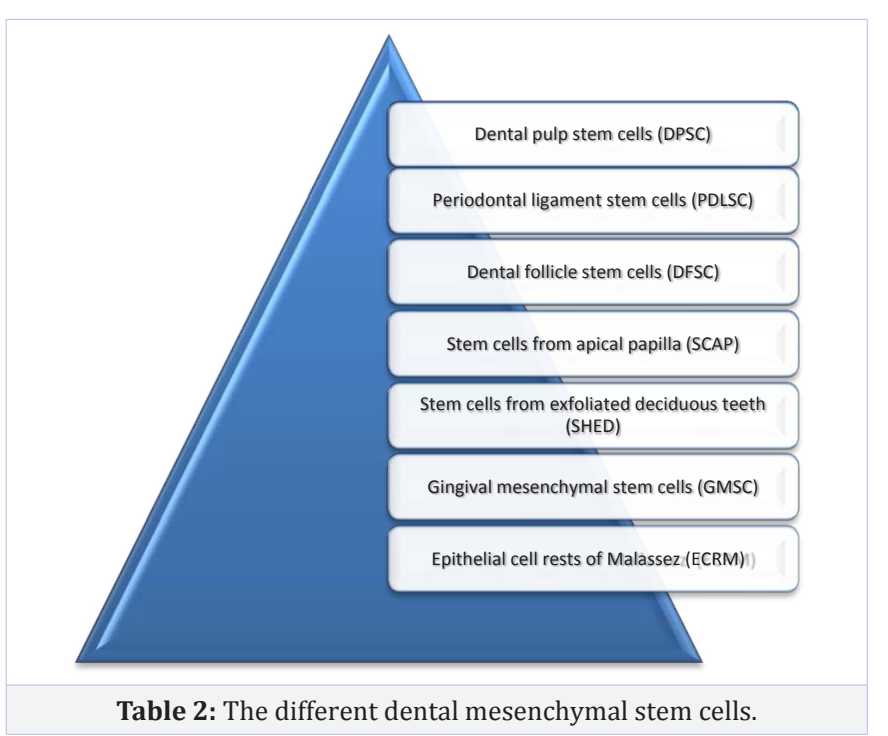




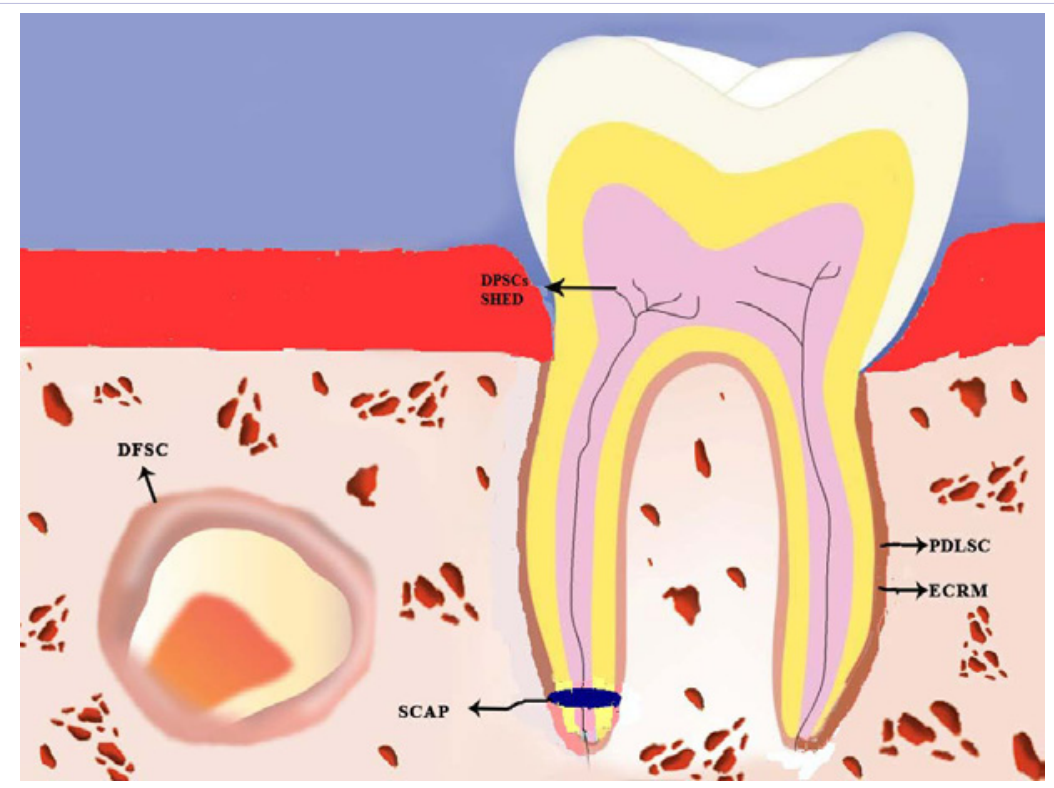

Figure 1: Schematic representation showing location of dental mesenchymal stem cells.

DPSC with osteogenic potential [53]. The osteoblasts obtained from these DPSC were compared with normal osteoblasts and numerous variations were found which might be responsible for the difference in bony tissue produced by these cells. Also the effect of these stem cells on periodontal regeneration has been inconsistent based on numerous studies done in beagle dogs till date $[54,55]$.

Periodontal Ligament stem cell (PDLSC): Periodontal ligament is a specialized connective tissue that connects cementum and alveolar bone, to maintain and hence support the teeth in sight also preserve tissue homeostasis. Multipotent stem cells from human periodontal ligament were isolated for the first time by Seo, et al. [56]. He reported that PDLSCs exhibited some characteristic features similar to BMMSCs [56]. The peculiar features were multipotency, clonogenic ability, high proliferation and expression of putative stem cell marker such as STRO-1 and perivascular cell marker CD 146 [49,57]. Like the BMMSCs they also express CD44, CD90, CD105, CD166. Scleraxis which is a transcription factor specific to tendon was found to be highly expressed by PDLSCs as compared to BMMSCs and DPSCs [58]. Hence it was concluded that periodontal ligament derived MSC are one of the most effective source for periodontal regeneration.

Park JY et al. [55] carried out a study in beagle dogs comparing PDLSCs with stem cells obtained from other dental sources and concluded that PDLSCs are most predictable in carrying out regeneration. Han et al. [59] created fenestration defects in murine models and placed allogeneic PDLSC to assess the time required for the defect to be mineralized. They observed that by day 14 and 21 significant amounts of mineralized tissue and bony bridge was formed. Ji, et al. [60] investigated the effect of PDLSCs derived from retained deciduous teeth (DePDLSC) in periodontal regeneration and compared it with PDLSCs derived from permanent teeth (PePDLSC). DePDLSCs were found to be comparatively immature hence readily differentiated into osteoblasts in osteogenic medium. Also, they were found to have the higher colony forming ability and increased proliferation rate as compared to PePDLSCs. Further DePDLSC cell sheets when combined with dentin blocks resulted in the formation of PDL and cementum like tissue on the dentin block however PePDLSCs resulted in formation of no cementum. Numerous other studies carried out in periodontal defect models in animals have reported positive results with application of PDLSC [61-64].

Stem cells from apical papilla (SCAP): Apical papilla is the soft tissue present at the apices of developing roots of permanent teeth. It is responsible for the formation of the radicular pulp hence SCAP resemble DPSCs however, they are comparatively more immature hence superior for tissue regeneration [65]. They are isolated from tips of developing roots, hence can be harvested easily during extraction of impacted third molars. In vitro characterization reveals MSC markers STRO-1, CD146 and CD24 which seem to be a unique feature of these cells [66]. They have been incorporated along with periodontal ligament stem cells in extraction sockets of miniature pigs, resulting in the successful formation of root and supporting periodontal structures [67]. They have been considered crucial in root formation which might be partly because, SCAP are the source of primary odontoblasts responsible for formation of root dentin [68].

Dental Follicle Stem Cells (DFSC): Dental follicle is an ectomesenchyme derived loose connective tissue sac surrounding the developing tooth bud from which arises the alveolar bone, cementum and periodontal ligament. DFSCs are relatively easy to harvest as can be procured from the follicles of unerupted third molars. In vitro characterization reveals stem cell markers Nestin, Notch-1 and STRO-1 [69]. They express vimentin (mesenchymal marker) and cementoblast markers (Cementum protein-23, Cementum attachment protein). Guo, et al. [70] has reported that 
DFSCs have the potential for regenerating the entire root of the teeth.

In support of the role of DFSCs in forming various periodontal structures, the authors discovered a crucial role played by Wnt5a [71]. Wnt5a proteins follow the non- canonical pathway involving tyrosine kinase like orphan receptor (ROR) proteins. These proteins have been found to play an important role in stimulating and regulating the role of DFSCs in forming non-mineralizing PDL and mineralized alveolar bone and cementum [71].

Stem cells from Human Exfoliated Deciduous teeth (SHED): In a study by Miura M, et al, [72] they found that multipotent stem cells are found in exfoliated human deciduous teeth. Hence, these cells can be readily harvested. They have a higher proliferation rate as compared to BMMSC and PDLSC, also result in increased bone formation [72]. SHED instead of directly forming the specific cells, create a special template for recruiting host cells, resulting in inducing the new tissue formation [72]. In vitro characterization reveals early MSC markers STRO-1 and CD146. Studies by Kerkis, et al. [73] revealed that they are basically immature DPSC and contain cell markers like Oct-4, Nanog which are present in embryonic stem cells.

$\mathrm{Fu}$, et al. [74] investigated the role of allogeneic SHED in the swine periodontitis model, and found that they resulted in predictable periodontal regeneration similar to PDLSCs. SHED have been found to elevate regulatory $T$ cells and downregulate T-helper 17 cells, hence have significant immunomodulatory capacity [75]. Also, Yamada, et al. [76] used SHED obtained from puppies and placed them in mandibular osseous defects created in parent canines. At 8 weeks the defect was completely filled with mature bone. Hence SHED derived from a child can be successfully used as graft in the parent.

Gingival Mesenchymal stem cells (GMSC): Oral MSCs derived from human gingiva (GMSCs) also have been considered as a promising alternative cell source for periodontal regeneration [77]. In addition to physical characteristics of gingival fibroblasts they exhibit adherence to plastic and multilineage differentiation potential [76]. In vitro characterization reveals cell surface markers CD44, CD73, CD90 and CD105 also stem cell markers such as SSEA-4, STRO-1, CD146, CD166, CD271 and vimentin which is a mesenchymal marker [78]. In a canine model with class III furcation defects, the transplanted
GMSCs significantly enhanced the regeneration of the damaged periodontal tissue, including the alveolar bone, cementum, and functional periodontal ligament [79].

Epithelial Cell Rests of Malassez (ECRM): These are remnants of the Hertwig's epithelial root sheath from which arise, all the periodontal structures. Since ECRM is normally present within the periodontium, hence studies have been carried out to research the stemness of ECRM [80-82]. They express MSC markers CD29, CD44, HSP-90 $\beta$ also embryonic stem cell markers Oct-4, Nanog and SSEA-4. Also Xiong J, et al. [82] has reported their capacity to carry out epithelial mesenchymal interactions. Following which numerous studies by the same authors have revealed that ECRM can differentiate into bone, cementum and periodontal ligament [80-82].

Hence, dental MSCs is a promising tool for periodontal regeneration. They have been found with similar characteristics as embryonic stem cells and other MSCs. Also, they are in many cases harvested from dental tissues which are to be discarded. Harvesting these cells is associated with minimal donor morbidity. However, there are a few limitations associated with their application as described in Table 3 [83].

\section{Induced Pluripotent stem cells}

Apart from the MSCs, experiments have been carried out to test whether somatic cells can be induced to transform into pluripotent stem cells. Takahashi, et al. [84] showed that adult somatic cells can be transformed into pluripotent stem cells by forcing expression of certain transcription factors. Hence, cells obtained from oral epithelium or other dental sources can be easily transformed to the desired cell type using the required transcription factors. These stem cells have drawn considerable attention since they are very similar to embryonic stem cells, hence considerable potential in periodontal regeneration [85]. Duan, et al. [86] has used these stem cells along with Emdogain in periodontal fenestration defect models resulting in the complete regeneration of the periodontium.

\section{Cell Sheet Engineering}

Although stem cells may be a promising source of periodontal regeneration, for better results they need to be transferred to the target site with appropriate scaffold and the correct signaling molecules for them to differentiate into the desired tissues.

Table 3: Limitations in the application of Dental MSC for periodontal regeneration [83].

\begin{tabular}{|c|c|c|}
\hline Biological & Technical & Clinical \\
\hline $\begin{array}{c}\text { Molecular pathways responsible for stem } \\
\text { cell proliferation and differentiation are } \\
\text { unknown }\end{array}$ & $\begin{array}{l}\text { Culture mediums are not well developed enough to mimic } \\
\text { in vivo conditions to ensure safe and consistent stem cell } \\
\text { proliferation and differentiation. } \\
\text { Stem cell line production for human trials could be hampered } \\
\text { by the use of xenogenic products in culture mediums as they } \\
\text { could be a potential source of pathogens. } \\
\text { Mesenchymal stem cells have a limited life span unlike } \\
\text { embryonic stem cells which are immortal } \\
\text { An ideal biocompatible scaffold and transport mechanism is } \\
\text { still under research. }\end{array}$ & $\begin{array}{l}\text { Integration of the human stem cell } \\
\text { derivatives with the recipient tissue and } \\
\text { their ability to carry out the desired } \\
\text { functions in humans is still under } \\
\text { speculation }\end{array}$ \\
\hline
\end{tabular}


Conventionally, tissue engineering involved the incorporation of cells, growth factors and scaffold separately into the defect. Over the years, researchers attempted at culturing cells in vitro under ideal conditions resulting in formation of cell sheets which were separated from the substratum by enzymatic treatment, and placed at the target site. This however was found to impair cell functions, since the proteolytic enzymes used hydrolyze various membrane associated proteins resulting in damage to the cell membrane. Pioneering work carried out by Okano, et al. [87] in the field of cell sheet engineering helped in overcoming this issue and making it a viable mode of periodontal regeneration.

Okano, et al. [87] incorporated a temperature responsive polymer poly(N-isopropylacrylamide) (PIPAAm) in the culture dishes to detach the cell sheets $[88,89]$. Since this polymer is hydrophilic at temperatures greater than $32^{\circ} \mathrm{C}$ and hydrophobic when temperature is reduced below $32^{\circ} \mathrm{C}$, also cells adhere to hydrophobic surfaces, therefore it is a useful aid in detaching the cells from the culture dishes.

Cell sheet engineering with the help of temperature responsive dishes can act as an effective means for periodontal regeneration. These temperature responsive cell sheets can be grafted to recipient site without suturing $[89,90]$. Figure 2 describes the technique of carrying out cell sheet engineering in temperature responsive culture dishes.

To increase the strength and number of cells, a 3D culture model of multilayered cell sheet have so been developed [91,92]. Also more recently cell sheet fragments and cell sheet pellets have been developed to increase the efficacy of the cells transplanted especially in cases where the target sit is too small for the entire cell sheet $[93,94]$. Further Co-culturing and micro-patterning of different types of cells are under trials for creation of more tissue-like materials which would give better results than single cell-sheets [95]. Also several researchers have attempted to incorporate biocompatible scaffolds like hyaluronic acid, fibrin gel and ceramic bovine bone to the fragile cell sheets also referred to as scaffold based cell sheet technology to improve the results following cell sheet engineering $[95,96]$. Hence cell sheets of the following types have been manufactured till date-

1. Monolayered Cell Sheets (MCS)

2. Multi-Layered cell-Sheet (MLS)

3. Cell Sheet Fragments (CSF)

4. Cell Sheet Pellets (CSP)

5. Co-culturing and micropatterning

6. Scaffold based CST

Cell sheet engineering has been extensively applied for periodontal regeneration by researchers in vitro and in animal studies. Table 4 illustrates the periodontal applications of cell sheet engineering [86-88, 91,92,95,97-100].

\section{Drawbacks of cell sheet engineering}

There are certain drawbacks associated with cell sheet engineering, which need to be addressed prior to clinical applications in patients. These cell sheets are extremely delicate which makes their handling and transportation without damage extremely difficult. Also numerous applications of multilayered cell sheets would be required to resemble the lost or damaged natural tissue. The high cost of this procedure is also a major impediment in making this treatment modality a reality [101].

\section{Future Directions}

Adequate numbers of stem cells in the target site have continued to be an impediment to the application of stem cells for periodontal regeneration. Cell reprogramming, which results in formation of induced pluripotent stem cells as discussed earlier

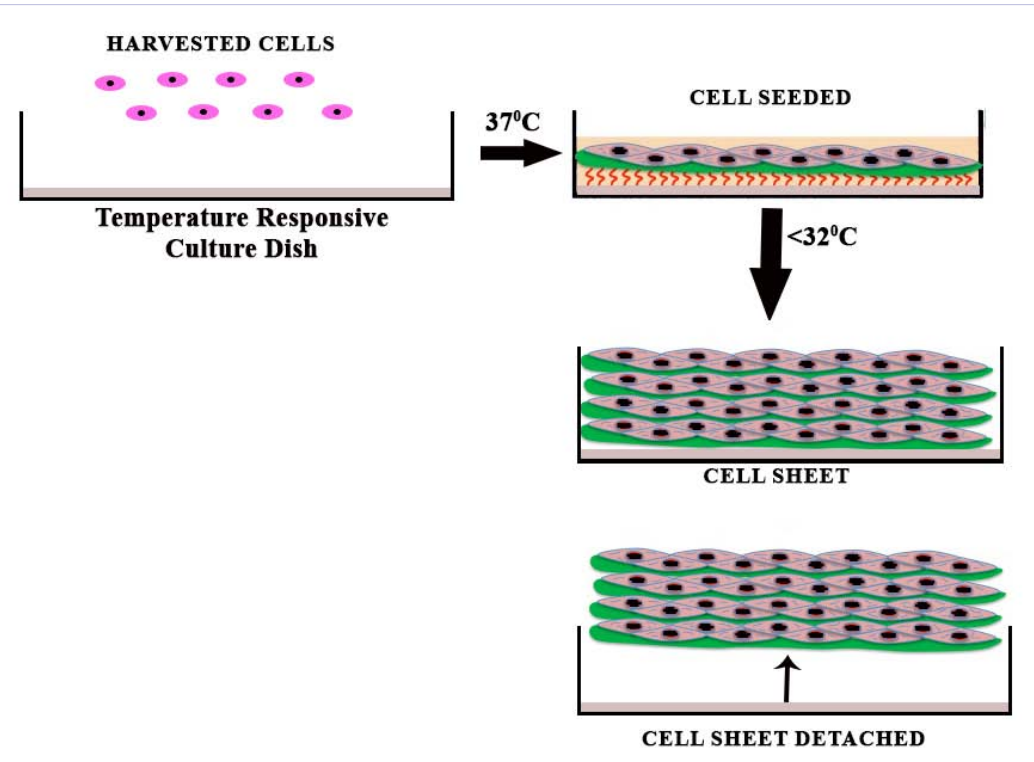

Figure 2: Schematic representation of the procedure of cell-sheet engineering. 
Table 4: Periodontal applications of cell sheet engineering.

\begin{tabular}{|c|c|c|c|}
\hline Author & Cell sheets & Target site & Results \\
\hline King GN, et al. 2001 [97] & $\begin{array}{l}\text { Human periodontal ligament } \\
\text { cell sheet (MCS)in osteogenic } \\
\text { differentiation medium }\end{array}$ & $\begin{array}{l}\text { Athymic rat mandible (King's } \\
\text { method) }\end{array}$ & $\begin{array}{l}\text { A layer of cementum \& new } \\
\text { attachment of collagen fibers to } \\
\text { cementum. }\end{array}$ \\
\hline Akizuki T, et al. 2005 [98] & $\begin{array}{l}\text { PDLSC cell sheets(MCS) using } \\
\text { hyaluronic acid as carrier from } \\
\text { temperature responsive culture } \\
\text { dish }\end{array}$ & $\begin{array}{l}\text { Mesial dehiscence model beagle } \\
\text { dogs }\end{array}$ & $\begin{array}{c}\text { Newly formed periodontal } \\
\text { ligaments with a rich capillary } \\
\text { supply found between alveolar bone } \\
\text { \& cementum. }\end{array}$ \\
\hline Flores MG, et al. 2008 [91] & PDLSC cell sheets(MLS) & Athymic rats & $\begin{array}{l}\text { Cementum like hard tissue on } \\
\text { dentin surface \& Collagen fibres } \\
\text { resembling periodontal \& sharpey's } \\
\text { fibers were inserted into tissue. }\end{array}$ \\
\hline Iwata, et al. 2009[92] & $\begin{array}{c}\text { PDLSC cell sheets(MLS) alongwith } \\
\text { TCP }\end{array}$ & $\begin{array}{l}\text { Surgically created three walled } \\
\text { defects in dogs }\end{array}$ & $\begin{array}{c}\text { New bone and Cementum was } \\
\text { formed with well-oriented collagen } \\
\text { fibres }\end{array}$ \\
\hline Bai, et al. 2011 [100] & DFSCs (MCS) alongwith HERS & Omenta of adult male rats & $\begin{array}{c}\text { DFSCs in presence of HERS formed } \\
\text { tissues resembling cementum and } \\
\text { periodontal ligament }\end{array}$ \\
\hline Xei, et al. 2012 [95] & $\begin{array}{l}\text { Co-cultured human PDLSC and } \\
\text { BMMSC alongwith ceramic bovine } \\
\text { bone powder (scaffold based CST) }\end{array}$ & Athymic rats & $\begin{array}{l}\text { Cementum and periodontal } \\
\text { ligament like tissue was formed } \\
\text { alongwith neovascularization }\end{array}$ \\
\hline $\mathrm{Na}$, et al. [87] & CSP of SCAP & In vitro & $\begin{array}{l}\text { Increased expression of alkaline } \\
\text { phosphatase, bone sialoprotein and } \\
\text { runt related gene-2 (RUNX2) mRNA } \\
\text { as compared to cell sheets }\end{array}$ \\
\hline Zhao, et al. 2013 [86] & CSF of PDLSCs and PRF granules & Reimplantation of teeth in dogs & $\begin{array}{c}\text { Better periodontal regeneration } \\
\text { and reduced Ankylosis and } \\
\text { inflammation }\end{array}$ \\
\hline
\end{tabular}

is under research to address this issue. Also, newer regeneration strategies such as scaffold based tissue engineering, modified cell pellet cultures, bioengineered tooth parts assembly and stem cell based gene therapy is being examined for this purpose.

Careful investigations need to be carried out to guarantee that the MSC would not form neoplasms.

Periodontium is a complex tissue comprising of 2 hard tissues (alveolar bone and cementum) and 2 soft tissues (periodontal ligament and gingiva). Complete regeneration implies the simultaneous production of all these tissues. To be able to achieve this extracellular matrix in the target site should generate the correct signals at the appropriate time for all the tissues to form.

Some authors have suggested the use of allogeneic MSC. However, further investigations need to be carried out to assess the feasibility of this approach, considering that in the clinical environment, complete regeneration needs to occur in a diseased environment containing inflammatory cytokines.

Further on various interactions between the different types of cells in the periodontium need to be assessed and also the effect of mechanical stress on periodontal regeneration needs to be examined in detail.

\section{References}

1. Pihlstrom BL, Michalowicz BS, Johnson NW. Periodontal diseases. Lancet. 2005; 366(9499): 1809-1820.

2. Albander JM. Epidemiology and risk factors of periodontal disease. Dent Clin North Am. 2005; 49(3): 517- 532.

3. Slade GD, Spencer AJ, Roberts-Thomson KF. Australian dental generation: the national survey of adult oral health 2004-06. Australian Institute of Health and Welfare; Canberra. available from www.aihw. gov.au/WorkArea/DownloadAsset.aspx?id=10737421983

4. Narayanan AS, Bartold PM. Biochemistry of periodontal connective tissues and their regeneration: a current perspective. Connect Tissue Res. 1996; 34(3): 191-201.

5. Register AA. Bone and cementum induction by dentin, demineralized in situ. J Periodontol 1973; 44(1): 235-246.

6. Nyman S, Lindhe J, Karring T, Rylander H. New attachment following 
surgical treatment of human periodontal disease. J Clin Periodontol 1982; 9(4): 290-296.

7. Bornstein MM, Bosshardt D, Buser D. Effect of two different bioresorbable collagen membranes on guided bone regeneration: a comparative histomorphometeric study in the dog mandible. J Periodontol 2007; 78(10):1943-1953.

8. Annen BM, Ramel CF, Hammerle CH, Jung RE. Use of a new cross-linked collagen membrane for the treatment of peri-implant dehiscence defects: a randomized control double-blinded clinical trial. Eur J Oral Implantol. 2011; 4: 87-100.

9. Ripamonti U, Reddi AH. Periodontal regeneration: potential role of bone morphogenetic proteins. J Periodont Res 1994; 29(4): 225-235.

10. Ten Cate AR. The role of epithelium in the development structure and function of the tissue of tooth support. Oral Dis 1996; 2(1): 55-62.

11. Hammarstrom L. Enamel matrix, cementum development and regeneration. J Clin Periodontol 1997; 24(9 Pt 2): 658-668.

12. Ramseier CA, Rasperini G, Batia S, Giannobile WV. Advanced reconstructive technologies for periodontal tissue repair. Periodontol 2000. 2012; 59(1): 185-202.

13. Hjørting-Hansen E. Bone grafting to the jaws with special reference to reconstructive preprosthetic surgery. A historical review. Mund Kiefer Gesichtschir 2002; 6(1): 6-14.

14. Burchardt H. The biology of bone graft repair. Clin Orthop Relat Res. 1983; 174: 28-42.

15. Cordaro L, Amade DS, Cordaro M. Clinical results of alveolar ridge augmentation with mandibular block bone grafts in partially edentulous patients prior to implant placement. Clin Oral Implants Res. 2002; 13(1): 103-111.

16. Garraway R, Young WG, Daley T, Harbow D, Bartold PM. An assessment of the osteoinductive potential of commercial demineralized freeze dreid bone in the murine thing muscle implantation model. J Periodontal 1998; 69(12): 1325-1336.

17. Needleman IG, Worthington HV, Giedrys-Leeper E, Tucker RJ. Guided tissue regeneration for periodontal infra-bony defects. Cochrane Database Syst Rev. 2006; 19(2): CD001724.

18. Esposito M, Grusovin MG, Papanikolaou N, Coulthard P, Worthington HV. Enamel matrix derivative (Emdogain(R)) for periodontal tissue regeneration in intrabony defects. Cochrane Database Syst Rev. 2009; 7(4): CD003875.

19. Nguyen TT, Mui B, Mehrabzadeh M, Chea Y, Chaudhry Z, Chaudhry $\mathrm{K}$, Tran SD. Regeneration of tissues of the oral complex: current clinical trends and research advances. J Can Dent Assoc. 2013; 79: d1.

20. Wang HL. Cooke J. Periodontal regeneration techniques for treatment of periodontal diseases. Dental Clin North Am. 2005; 49(39): 637-59.

21. Sanz M, Giovannoli JL. Focus on furcation defects: guided tissue regeneration. Periodontol 2000. 2000; 22:169-89.

22. Langer R,Vacanti JP. Tissue engineering. Science 1993; 260(5110): 920-926.

23. Slavkin HC, Bartold PM. Challenges and potential in tissue engineering. Periodontol 2000. 2006; 41:9-15.

24. Srisuwan T, Tilkorn DJ, Wilson JL, Morrison WA, Messer HM, Thompson EW, et al. Molecular aspects of tissue engineering in the dental field. Periodontol 2000. 2006; 41:88-108.

25. Kawaguchi H, Hirachi A, Hasegawa N, Iwata T, Hamaguchi H, Shiba H, et al. Enhancement of periodontal tissue regeneration by transplant of bone marrow mesenchymal stem cells. J Periodontol. 2004; 75(9): 1281-1287.

26. Kemppainen JM, Hollister SJ. Tailoring the mechanical properties of 3D-designed poly (glycerol sebacate) scaffolds for cartilage applications. J Biomed Mater Res A. 2010; 94(1):9-18.

27. Graziano A, d'Aquino R, Cusella-De Angelis MG, De Francesco F, Giordano A, Laino G, et al. Scaffold's surface geometry significantly affects human stem cell bone tissue engineering. J Cell Physiol. 2008; 214(1):166-172.

28. Nicholas C, Lesinski GB. Immunomodulatory cytokines as therapeutic agents for melanoma. Immunotherapy 2011; 3(5):673-90.

29. Nor JE. Tooth regeneration in operative dentistry. Oper Dent. 2006; 31(6):633-642.

30. Hynes K, Menicanin D, Gronthos S, Bartold PM. Clinical utility of stem cells for periodontal regeneration. Periodontol 2000. 2012; 59:203227.

31. Lin NH, Gronthos S, Bartold PM. Stem cells and periodontal regeneration. Aust Dent J 2008; 53(2):108-121.

32. Egusa H, Sonoyama W, Nishimura M, Atsuta I, Akiyama K. Stem cells in dentistry--Part II: Clinical applications. J Prosthodont Res. 2012; 56(4):229-248.

33. Gault P, Black A, Romette JL, Fuente F, Schroeder K, Thillou F, et al. Tissue-engineered ligament: implant constructs for tooth replacement. J Clin Periodontol.2010; 37(8):750-758.

34. Han J, Menicanin D, Gronthos S, Bartold PM. Stem cells, tissue engineering and periodontal regeneration. Aust Dent J. 2014; 59:117130.

35. Smith A. A glossary for stem cell biology. Nature 2006; 441: 1060 .

36. Mehta DS, Jyothy TM, Kumar T. Stem Cells in dentofacial research-At the Cross Roads. J Indian Soc Periodontol 2005; 9:91-108.

37. Nakao K, Morita R, Saji Y, Ishida K, Tomita Y, Ogawa M, et al. The development of a bioengineered organ germ method. Nat Methods. 2007; 4(3):227-30.

38. Ikeda E, Morita R, Nakao K, Ishida K, Nakamura T, Takano-Yamamoto $\mathrm{T}$, et al. Fully functional bioengineered tooth replacement as an organ replacement therapy. Proc Natl Acad Sci U S A. 2009; 106(32): 1347580.

39. Amos TA, Gordon MY. Sources of human hematopoietic stem cells for transplantation- a review. Cell Transplant 1995; 4(6): 547-569.

40. Smith C, Stroms B. Hematopoietic stem cells. Clin Orthop Relat Res 2000; 379: S91-97.

41.Toma JG, Akhavan M, Fernandes KJ, Barnabe-Heider F, Sadikot A, Kaplan DR. Isolation of multipotent adult stem cells from the dermis of mammalian skin. Nat Cell Biol. 2001; 3(9):778 -784.

42. Caplan AI. Mesenchymal stem cells. J Orthop Res. 1991 Sep; 9(5):64150 .

43. Prockop DJ. Marrow stromal cells as stem cells for nonhematopoietic tissues. Science. 1997; 276(5309):71-4.

44. Pittenger MF, Mackay AM, Beck SC, Jaiswal RK, Douglas R, Mosca JD, et al. Multilineage potential of adult human mesenchymal stem cells. Science 1999; 284(5411): 143-7.

45. Ponnaiyan D. Do dental stem cells depict distinct characteristics? - 
Establishing their "phenotypic fingerprint". Dent Res J (Isfahan). 2014; 11(2):163-72.

46. Bianco P, Riminucci M, Gronthos S, Robey PG. Bone marrow stromal stem cells: nature, biology and potential applications. Stem cells 2001; 19(3):180-192.

47. Kawaguchi H, Hirachi A, Hasegawa N, Iwata T, Hamaguchi H, Shiba H, et al. Enhancement of periodontal tissue regeneration by transplantation of bone marrow mesenchymal stem cells. J Periodontol 2004; 75(9):1281-1287.

48. Yamada Y, Ueda M, Hibi H, Baba S. A novel approach to periodontal tissue regeneration with mesenchymal stem cells and platelet-rich plasma using tissue engineering technology: a clinical case report. Int J Periodontics Restorative Dent. 2006; 26(4): 363-369.

49. Gronthos S, Mankani M, Brahim J, Robey PG, Shi S. Postnatal human dental pulp stem cells(DPSCs) in vitro and in vivo. Proc Natl Acad Sci USA. 2000; 97(25):13625 -13630.

50. Gronthos S, Brahim J, Li W, Fisher LW, Cherman N, Boyde A, et al. Stem cell properties of human dental pulp stem cells. J Dent Res. 2002; 81(8):531-5.

51. Ponnaiyan D, Bhat KM, Bhat GS. Comparison of immuno-phenotypes of stem cells from human dental pulp and periodontal ligament. Int J Immunopathol Pharmacol. 2012; 25(1):127-34.

52. Grzesik WJ, Kuzentsov SA, Uzawa K, Mankani M, Robey PG, Yamauchi M. Normal human cementum-derived cells: isolation, clonal expansion, and in vitro and in vivo characterization. J Bone Miner Res. 1998; 13(10):1547-54.

53. Carinci F, Papaccio G, Laino G, Palmieri A, Brunelli G, D’Aquino R, et al. Comparison between genetic portraits of osteoblasts derived from primary cultures and osteoblasts obtained from human pulpar stem cells. J Craniofac Surg. 2008; 19(3):616-25.

54. Ji YM, Jeon SH, Park JY, Chung JH, Choung YH, Choung PH. Dental stem cell therapy with calcium hydroxide in dental pulp capping. Tissue Eng Part A 2010; 16(6):1823-1833.

55. Park JY, Jeon SH, Choung PH. Efficacy of periodontal stem cell transplantation in the treatment of advanced periodontitis. Cell Transplant 2011; 20(2): 271-285.

56. Seo BM, Miura M, Sonoyama W, Coppe C, Stanyon R, Shi S. Recovery of stem cells from cryopreserved periodontal ligament. J Dent Res 2005; 84(10):907-912.

57. Trubiani 01, Di Primio R, Traini T, Pizzicannella J, Scarano A, Piattelli A, et al. Morphological and cytofluorimetric analysis of adult mesenchymal stem cells expanded ex vivo from periodontal ligament. Int J Immunopatholol Pharmacol 2005; 18(2):213-221.

58. Seo BM, Miura M, Gronthos S, Bartold PM, Batouli S, Brahim J, et al. Investigation of multipotent postnatal stem cells from human periodontal ligament. Lancet 2004; 364(9429):149-55.

59. Han J, Menicanin D, Marino V, Ge S, Mrozik K, Gronthos S, et al. Assessment of the regenerative potential of allogeneic periodontal ligament stem cells in a rodent periodontal defect model. J Periodont Res 2014; 49(3): 333-345.

60. Ji K, Liu Y, Lu W, Yang F, Yu J, Wang X, et al. Periodontal tissue engineering with stem cells from the periodontal ligament of human retained deciduous teeth. J Periodont Res 2013; 48(1):105-116.

61. Feng F, Akiyama K, Liu Y, Yamaza T, Wang TM, Chen JH, et al. Utility of PDL progenitors for in vivo tissue regeneration: a report of 3 cases. Oral Dis. $2010 ; 16(1): 20-28$.
62. Lang H, Schuler N, Arnhold S, Nolden R, Mertens T. Formation of differentiated tissues in vivo by periodontal cell populations cultured in vitro. J Dent Res 1995; 74(5): 1219-1225.

63. Liu Y, Zheng Y, Ding G, Fang D, Zhang C, Bartold PM, et al. Periodontal ligament stem cell- mediated treatment for periodontitis in miniature swine. Stem Cells 2008; 26(4):1065-1073.

64. Otaki S, Ueshima S, Shiraishi K, Sugiyama K, Hamada S, Yorimoto M, et al. Mesenchymal progenitor cells in adult human dental pulp and their ability to form bone when transplanted into immunocompromised mice. Cell Biol Int. 2007; 31(10):1191-7.

65. Huang J, Gronthos S, Shi S. Mesenchymal stem cells derived from dental tissues vs those from other sources: their biology and role in regenerative medicine. J Dent Res 2009; 88(9):792-806.

66. Sonoyama W, Liu Y, Yamaza T, Tuan RS, Wang S, Shi S, et al. Characterization of the apical papilla and its residing stem cells from human immature permanent teeth: a pilot study. J Endod. 2008; 34(2):166-71.

67. Sonoyama W, Liu Y, Fang D, Yamaza T, Seo BM , Zhang C, et al. Mesnchymal stem cell-mediated functional tooth regeneration in swine. PLoS ONE. 2006; 1: e79.

68. Seo BM, Sonoyama W, Yamaza T, Coppe C, Kikuiri T, Akiyama K, et al. SHED repair critical size calvarial defects in mice. Oral Dis 2008; 14(5): 428-434.

69. Morsczeck C, Völlner F, Saugspier M, Brandl C, Reichert TE, Driemel 0 , et al. Comparison of human dental follicle cells (DFCs) and stem cells from human exfoliated deciduous teeth (SHED) after neural differentiation in vitro. Clin Oral Investig. 2010; 14 (4):433-40.

70. Guo W, He Y, Zhang X, Lu W, Wang C, Yu H, et al. The use of dentin matrix scaffold and dental follicle cells for dentin regeneration. Biomaterials 2009; 30(35):6708-6723.

71.Xiang L, Chen M, He L, Cai B, Du Y, Zhang X, et al. Wnt5a regulates dental follicle stem/progenitor cells of the periodontium. Stem Cell Res Ther. 2014; 5(6):135.

72. Miura M, Gronthos S, Zhao M, Lu B, Fisher LW, Robey PG, et al. SHED: stem cells from human exfoliated deciduous teeth. Proc Natl Acad Sci USA 2003; 100(10):5807-5812.

73. Kerkis I, Kerkis A, Dozortsev D, Stukart-Parsons GC, Gomes Massironi $\mathrm{SM}$, Pereira LV, et al. Isolation and characterization of a population of immature dental pulp stem cells expressing OCT-4 and other embryonic stem cell markers.Cells Tissues Organs. 2006; 184(34):105-16.

74. Fu X, Jin L, Ma P, Fan Z, Wang S. Allogenic stem cells from deciduous teeth in treatment for periodontitis in miniature swine. J Periodontol 2014; 85(6):845-851.

75. Yamaza T, Kentaro A, Chen C, Liu Y, Shi Y, Gronthos S, et al. Immunomodulatory properties of stem cells from human exfoliated deciduous teeth. Stem Cell Res Ther 2010; 1(1):5.

76. Yamada Y, Ito K, Nakamura S, Ueda M, Nagasaka T. Promising cell-based therapy for bone regeneration using stem cells from deciduous teeth, dental pulp and bone marrow. Cell Transplant 2011; 20(7):1003-1013.

77. Yang H, Gao LN, An Y, Hu CH, Jin F, Zhou J, et al. Comparison of mesenchymal stem cells derived from gingival tissue and periodontal ligament in different incubation conditions. Biomaterials 2013; 34(29):7033-47.

78. Jin SH, Lee JE, Yun JH, Kim I, Ko Y, Park JB. Isolation and characterization 
of human mesenchymal stem cells from gingival connective tissue. J Periodontal Res. 2014; [Epub ahead of print].

79. Yu X, Ge S, Chen S, Xu Q, Zhang J, Guo H, et al. Human gingiva-derived mesenchymal stromal cells contribute to periodontal regeneration in beagle dogs. Cells Tissues Organs. 2013; 198(6):428-37.

80. McDermott SP, Eppert K, Lechman ER, Doedens M, Dick JE. Comparison of human cord blood engraftment between immunocompromised mouse strains. Blood 2010; 116(2):193-200.

81. Nam H, Kim J, Park J, Park JC, Kim JW, Seo BM, et al. Expression profile of the stem cell markers in the Hertwig's Epithelial root sheath Epithelial rests of Malassez cells. Mol Cells 2011; 31(4):355-360.

82.Xiong J, Mrozik KM, Gronthos S, Bartold PM. Epithelial cell rests of malassez contain unique stem cell populations capable of undergoing epithelial mesenchymal transition. Stem Cells Dev 2012; 21(11):20122025.

83. Lin NH, Gronthos S, Bartold PM. Stem cells and future periodontal regeneration. Periodontol 2000. 2009; 51:239-251.

84. Takahashi K, Tanabe K, Ohnuki M, Narita M, Ichisaka T, Tomoda K, et al. Induction of pluripotent stem cells from adult human fibroblast by defined factors . Cell. 2007; 131(5):861-872.

85. Takahashi K, Yamanaka S. Induction of pluripotent stem cells from mouse embryonic and adult fibroblast cultures by defined factors. Cell. 2006; 126(4):663-676.

86. Duan X, Tu Q, Zhang J, Ye J, Sommer C, Mostoslavsky G, et al Application of induced pluripotent stem (iPS) cells in periodontal tissue regeneration. J Cell Physiol. 2011: 226(1): 150-157.

87. Okano T, Bae YH, Jacobs H, Kim SW. Thermally on-off switching polymers for drug permeation and release. J Control Release 1990; 11(1-3): 255-265.

88. Yamada N, Okano T, Sakai H, Karikusa F, Sawasaki Y, Sakurai Y Thermo-responsive polymeric surfaces; control of attachment and detachment of cultured cells. Makromol Chem Rapid Commun. 1990; 11(11):571-576.

89. Nishida K, Yamato M, Hayashida Y,Watanabe K, Yamamoto K, Adachi $\mathrm{E}$, et al. Corneal reconstruction with tissue-engineered cell sheet composed of autologous oral mucosal epithelium. N Engl J Med. 2004; 351(12):1187-1196.

90. Ohki T ,Yamato M, Murakami D, Takagi R, Yang J , Namiki H, et al. Treatment of oesophageal ulcerations using endoscopic transplantation of tissue-engineered autologous oral mucosal epithelial cell sheets in a canine model. Gut 2006; 55(12):1704-1710.

91. Flores MG, Yashiro R, Washio K, Yamato M, Okano T, Ishikawa I. Periodontal ligament cell sheet promotes periodontal regeneration in athymic rats. J Clin Periodontol. 2008; 35(12):1066-1072.

92. Iwata T, Yamato $M$, Tsuchioka $H$, Takagi R, Mukobata S, Washio $\mathrm{K}$, et al. Periodontal regeneration with multi-layered periodontal ligamentderived cell sheets in a canine model. Biomaterials 2009; 30(14): 2716-23.

93. Na S, Zhang H, Huang F, Wang W, Ding Y, Li D, et al. Regeneration of dental pulp/dentine complex with a three-dimensional and scaffoldfree stem-cell sheet-derived pellet. J Tissue Eng Regenerative Med. 2013; [Epub ahead of print].

94. Zhao YH, Zhang M, Liu NX, Lv X, Zhang J, Chen FM, et al. The combined use of cell sheet fragments of periodontal ligament stem cells and platelet-rich fibrin granules for avulsed tooth reimplantation. Biomaterials 2013; 34(22):5506-20.

95.Xie H, Liu H. A novel mixed-type stem cell pellet for cementum/ periodontal ligament-like complex. J Periodontol. 2012; 83(6):805-15.

96. Dan H, Vaquette C, Fisher AG, Hamlet SM, Xiao Y, Hutmacher DW, et al. The influence of cellular source on periodontal regeneration using calcium phosphate coated polycaprolactone scaffold supported cell sheets. Biomaterials 2014; 35(1):113-22.

97. King GN, Hughes FJ. Bone morphogenetic protein-2 stimulates cell recruitment and cementogenesis during early wound healing. J Clin Periodontol. 2001; 28(5):465-475.

98. Akizuki T, Oda S, Komaki M, Tsuchioka H, Kawakatsu N, Kikuchi A, et al. Application of periodontal ligament cell sheet for periodontal regeneration: a pilot study in beagle dogs. J Periodontal Res. 2005; 40(3): 245-251.

99. Ding G, Liu Y, Wang W, Wei F, Liu D, Fan Z, et al. Allogeneic periodontal ligament stem cell therapy for periodontitis in swine. Stem Cells. 2010; 28(10): 1829-38.

100. Bai Y, Bai Y, Matsuzaka K, Hashimoto S, Fukuyama T, Wu L, et al. Cementum-and periodontal ligament-like tissue formation by dental follicle cell sheets cocultured with Hertwig's epithelial root sheath cells. Bone 2011; 48(6): 1417-26.

101. Wang J, Zhang R, Shen Y, Xu C, Qi S, Lu L, et al. Recent advances in cell sheet technology for periodontal regeneration. Current Stem Cell Research \& Therapy 2014; 9(3):162-173. 